New Developments in Sheep Production

Occasional Publication No. 14-British Society of Animal Production 1990

edited by C. F. R. Slade and T. L. J. Lawrence

\title{
INFLUENCE OF SHEARING TREATMENT ON THE PERFORMANCE OF PREGNANT EWES OFFERED SILAGE ON AN AD LIBITUM OR RESTRICTED BASIS
}

\author{
H. J. BLACK and D. M. B. CHESTNUTT
}

Agricultural Research Institute of Northern Ireland, Hillsborough, Co. Down BT26 6DP

\section{INTRODUCTION}

$\mathbf{R}$ esults from an earlier experiment have shown that shearing ewes during pregnancy can increase lamb birth weight (Black and Chestnutt, 1990). Such increases may be the result of increased voluntary food intake after shearing. In some trials where intake of shorn ewes has been restricted to the level of unshorn ewes, lamb birth weights were not increased (Russel, Armstrong and White, 1985). Other trials have however indicated that shearing exerts its effect on lamb birth weight independently of food intake (Rutter, Laird and Broadbent, 1972; Vipond, King, Inglis and Hunter, 1987). An experiment was therefore designed to examine how these factors operate by offering shorn ewes the same silage either ad libitum or at a restricted level to give equalized intakes between shearing treatments throughout pregnancy. Ewes on both silage treatments were shorn at different stages throughout pregnancy since previous information suggested that lamb birth weight response to shearing declines in ewes shorn later than week 15 of gestation (Black and
Chestnutt, 1990). Performance of the ewes during the first 5 weeks of lactation was studied to assess their ability to withstand cold conditions after turn-out.

\section{MATERIAL AND METHODS}

The experiment was designed as a $5 \times 2$ factorial arrangement of two silage and five shearing treatments. A flock of Greyface ewes was synchronized in oestrus and progesterone concentrations in the blood at day 19 from mating were used as the basis for selecting 60 pregnant ewes. Precision-chop silage (digestible organic matter (DOM) $762 \mathrm{~g} / \mathrm{kg}$ dry matter (DM)) was offered on an ad libitum (proportionately 0.10 refusal) or restricted basis ( $10 \mathrm{~g} \mathrm{DM}$ per $\mathrm{kg}$ fasted live weight) to the ewes throughout the 13 -week housing period. A total of $21 \mathrm{~kg}$ concentrates was offered to each ewe on an increasing scale over the last 7 weeks of pregnancy. Ewes were shorn at either 10,6 or 4 weeks before lambing (treatments S10, S6 and S4) at each of 10,6 and 4 weeks before lambing (treatment ST) or remained

TABLE 1

Influence of shearing and silage treatments on ewe performance during housing

Shearing treatment

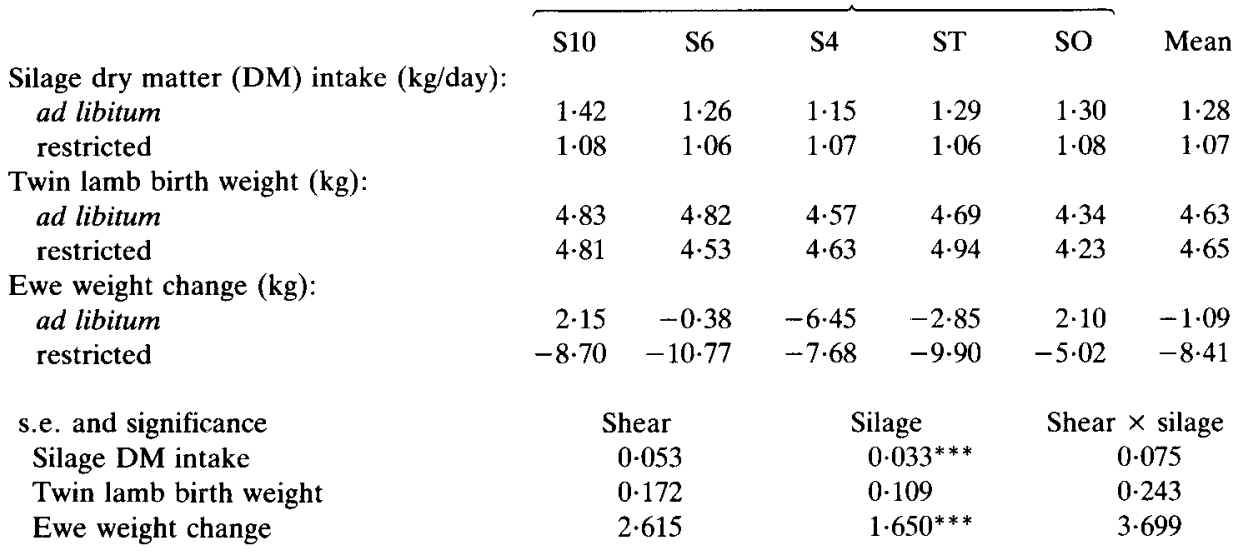


unshorn throughout pregnancy (treatment SO). Intakes for ewes offered ad libitum silage were calculated on a weekly basis from records of intakes and refusals kept for 4 days each week. Ewes were weighed weekly and scored for body condition at intervals of 2 weeks. After each shearing, rates of respiration and rectal temperatures were recorded in all the ewes. Lambing was induced and lambs were weighed and sexed at birth. Ewes were weighed after lambing. Ewes and lambs were turned out to grass within 2 days of lambing and weights were recorded at weekly intervals over the first 5 weeks of lactation. Milk secretion rates of the ewes were measured over 4 -h periods, 15 and 30 days after lambing, by hand milking after oxytocin injections.

\section{RESULTS}

Average silage DM intakes for the housing period are shown in Table 1. As intended, average DM intake was lowered by silage restriction and equalized between shearing treatments. In ewes offered silage ad libitum, DM intake was not significantly different between shearing treatments. Compared with 3 weeks before shearing, the change in intake in the 3 -week period after shearing was $-8,+78$ and $+138 \mathrm{~g} /$ day (s.e. $72 \cdot 4$ ) for treatments $\mathrm{S} 10, \mathrm{~S} 6$ and $\mathrm{S} 4$ respectively, indicating a greater immediate response in intake from ewes shorn late in pregnancy. Level of silage intake had no significant effect on lamb birth weight as shown in Table 1. On both silage treatments there was a tendency for lambs from shorn ewes to be heavier than those from unshorn ewes although this just failed to reach statistical significance at the $5 \%$ probability level $(P=0.063)$. The stage of pregnancy at which ewes were shorn did not significantly influence lamb birth weight at either level of silage intake. On average, ewes on both silage treatments lost weight over pregnancy with significantly greater losses in those whose intake was restricted (Table 1). Shearing did not significantly influence live-weight change in ewes. The change in ewe body condition score over pregnancy showed a similar response to that of ewe live-weight change.

Shearing significantly reduced respiration rates and rectal temperatures as shown in Table 2 .

Ewe performance after turn-out is shown in Table 3. There were no significant treatment effects on either ewe weight change or lamb growth rates. Milk yields at the two milking dates were combined and results indicate no significant carry-over effects of treatments applied during housing.

\section{DISCUSSION}

Variable increases in lamb birth weight ranging from $0.5 \mathrm{~kg}$ per lamb (Kirk, Cooper and Chapman, 1984) to almost $1.0 \mathrm{~kg}$ per lamb (Black and Chestnutt, 1990) have been produced by shearing ewes during pregnancy. Dispute arises as to whether shearing acts directly to influence lamb birth weights or whether it exerts its influence by increasing voluntary food intake. In the current experiment, shearing ewes offered silage on an ad libitum or restricted basis increased lamb birth weights by an average of $0.39 \mathrm{~kg}$ per lamb and $0.50 \mathrm{~kg}$ per lamb respectively. Such increases occurred in the absence of any change in intake which did not differ significantly between shearing treatments. Ewes offered ad libitum silage had higher intakes and lost less weight over pregnancy than ewes whose silage intake was restricted. Despite this however, average lamb birth weights on the two silage treatments were equal (4.63v. $4.65 \mathrm{~kg}$ per lamb; s.e. 0.109). Similar results were presented by Rutter et al. (1972) and Black and Chestnutt (1990) who found that shearing produced much larger increases in lamb birth weight $(0.6$ and $0.74 \mathrm{~kg}$ per lamb respectively) than did different intakes of energy in late pregnancy $(0.3$ and $0.02 \mathrm{~kg}$ per lamb respectively). It appears that shearing exerts its influence on lamb birth weight independently of voluntary food intake.

Earlier studies have shown that severe heat stress

TABLE 2

Change (values immediately before minus values immediately after shearing) in respiration rate and rectal temperature as a result of shearing

\begin{tabular}{|c|c|c|c|c|c|c|c|}
\hline & $\begin{array}{l}\text { Weeks } \\
\text { before } \\
\text { lambing }\end{array}$ & \multicolumn{5}{|c|}{ Treatment } & \\
\hline $\begin{array}{l}\text { Respiration rate } \\
\text { (breaths per minute) }\end{array}$ & $\begin{array}{c}\text { lambing } \\
10 \\
6 \\
4\end{array}$ & $\begin{array}{l}\mathbf{S} 10 \\
-34\end{array}$ & $\begin{array}{r}\text { S6 } \\
-38\end{array}$ & $\begin{array}{r}\text { S4 } \\
-27\end{array}$ & $\begin{array}{r}\text { ST } \\
-31 \\
-2 \\
-7\end{array}$ & $\begin{aligned} & \text { SO } \\
&+ 10 \\
&+11 \\
&+\quad 4\end{aligned}$ & $\begin{array}{c}\text { S.e. and } \\
\text { significance } \\
7 \cdot 7^{* * *} \\
6 \cdot 6^{* * *} \\
9 \cdot 8^{* *}\end{array}$ \\
\hline ectal temperature & $\begin{array}{r}10 \\
6 \\
4\end{array}$ & -0.58 & -0.41 & -0.78 & $\begin{array}{l}-0.34 \\
+0.20 \\
+0.66\end{array}$ & $\begin{array}{l}-0.07 \\
+0.01 \\
+0.13\end{array}$ & $\begin{array}{l}0 \cdot 136^{* *} \\
0 \cdot 134^{* * *} \\
0 \cdot 435^{* *}\end{array}$ \\
\hline
\end{tabular}


TABLE 3

Ewe and lamb performance at grass

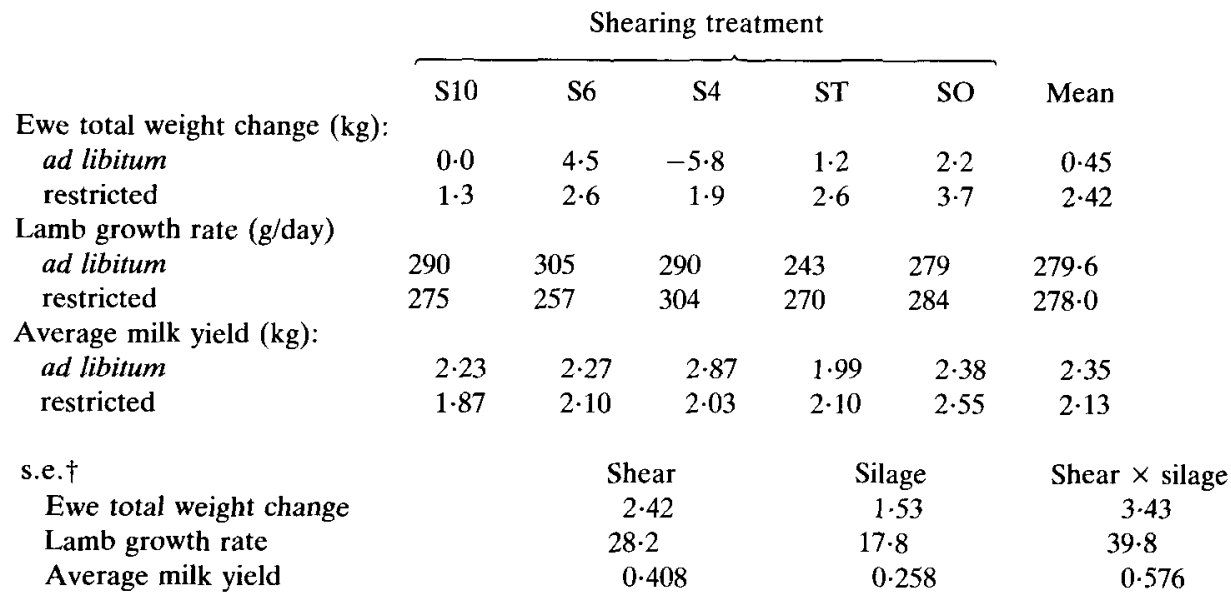

$\dagger$ Differences for shearing, silage and shearing $\times$ silage interaction were not significant $(P>0.05)$.

(44.4 $4^{\circ} \mathrm{C}$ and $32.5 \mathrm{~mm} \mathrm{Hg}$ vapour pressure) can cause foetal and placental stunting resulting in dwarf lambs (Alexander and Williams, 1971). Although maximum respiration rates and rectal temperature recorded in the current experiment were not as high as those recorded by Alexander and Williams (1971), it is possible that the unshorn ewes were subjected to moderate heat stress and that this may have lowered lamb birth weights. Shearing ewes overcomes the problems of heat stress as indicated by the significant drop in respiration rate and rectal temperature.

At turn-out to grass, ewes in treatment $\mathbf{S 4}$ carried less than $1 \mathrm{~cm}$ of fleece regrowth compared with about 2 to $3 \mathrm{~cm}$ in treatment $\mathrm{S} 10$ and a full fleece in treatment $S O$. Despite this and the cold, wet weather conditions following turn-out, there were no significant carry-over effects of shearing or silage treatments on ewe weight change or lamb growth rates. Milk yields were variable between ewes and there was no significant treatment effect. Wodzicka-Tomaszewska (1958) showed skin thickening occurs soon after shearing and this may account for the lack of any shearing effect observed here.

\section{REFERENCES}

Alexander, G. and Williams, D. 1971. Heat stress and the development of the conceptus in domestic sheep. Journal of Agricultural Science, Cambridge 76: 53-72.

Black, H. J. and ChestnutT, D. M. B. 1990. Influence of shearing regime and silage quality on the performance of pregnant and lactating ewes. Animal Production 51: In press.

Kirk, J. A., CoOper, R. A. and Chapman, A. 1984. Effect of shearing housed pregnant ewes on their plasma glucose levels, lamb birth weight and lamb growth rate to 56 days. Animal Production 38: 524 (Abstr.).

Ministry of Agriculture, Fisheries and Food. 1982. Winter shearing of housed ewes. $A D A S$ Annual Report, 1981, 27-28.

Russel, A. J. F., Armstrong, R. H. and White, I. R. 1985. Studies on the shearing of housed pregnant ewes. Animal Production 40: 47-53.

Rutter, W., Laird, T. R. and Broadbent, P. J. 1972. A note on the effects of clipping pregnant ewes at housing. Animal Production 14: 127-130.

VIPOND, J. E., KING, M. E., InGLis, D. M. and Hunter, E. A. 1987. The effect of winter shearing of housed pregnant ewes on food intake and animal performance. Animal Production 45: 211-221.

Wodzicka-Tomaszewska, M. 1958. Studies of the thickness and chemical composition of the skin of the sheep. III. Effect of shearing. New Zealand Journal of Agricultural Research 1: 601-606. 